\title{
A Revision of the Osmerid Genus Hypomesus Gill (Teleostei: Salmoniformes), with the Description of a New Species from the Southern Kuril Islands
}

\author{
Toshiro Saruwatari', Juan Andrés López², and Theodore W. Pietsch² \\ 'Division of Biology of Fisheries Resources, Ocean Research Institute, University of Tokyo, \\ 1-15-1 Minamidai, Nakano-ku, Tokyo, 164, Japan \\ ${ }^{2}$ School of Fisheries, University of Washington, Box 355100, Sealtle, \\ Washington 98195-5100, USA
}

(Received 30 August 1996; Accepted 30 April 1997)

\begin{abstract}
A systematic revision of the osmerid genus Hypomesus Gill, based on a detailed analysis of external and internal morphological characters, revealed the presence of six species, one of which is described as new. These six species fall readily into three species-groups: the Hypomesus nipponensis group, containing $H$. nipponensis McAllister, $H$. chishimaensis new species, and $H$. transpacificus McAllister; the $H$. olidus group, containing only $H$. olidus Pallas; and the $H$. japonicus group, containing $H$. japonicus Brevoort and $H$. pretiosus Girard. Synonymies, diagnoses, and descriptions are given for all taxa, geographic distributions are described and plotted, and a key to the species of the genus is provided.

Key Words: Teleostei, Salmoniformes, Osmeridae, Hypomesus, new species, revisionary studies, Kuril Islands, Kunashir, Iturup, Zelionyi
\end{abstract}

\section{Introduction}

The genus Hypomesus, family Osmeridae, contains relatively small fishes that inhabit fresh, brackish, and coastal marine waters of the northern Pacific Rim. Most members of the group are commercially exploited for human consumption and recreational fishing. McAllister (1963), in the most current taxonomic revision of the genus, recognized three species and four subspecies (Table 1). Based primarily on osteological characters, Kljukanov $(1970 \mathrm{a}, \mathrm{b})$ elevated these subspecies to full species rank; but while Kljukanov's work was an improvement over past interpretations, he still left the nomenclature of the genus in disarray.

Our interest in Hypomesus was initiated by attempts to identify material collected in the southern Kuril Islands during the 1994 expedition of the International Kuril Island Project, a biotic survey and inventory of the Kuril Islands funded jointly by the U.S. National Science Foundation, the Japan Society for the Promotion of Science, and the Far East Branch of the Russian Academy of Sciences. This new material, which has proven to represent an undescribed species of Hypomesus, along with preserved specimens borrowed from various institutions and additional newly collected specimens from Japanese localities, forms the basis for the following revision. 
Table 1. Reallocation of nominal taxa of the genus Hypomesus.

\begin{tabular}{ll}
\hline \multicolumn{1}{c}{ Nominal taxon } & \multicolumn{1}{c}{ Senior synonym } \\
\hline Salmo olidus Pallas, 1814 & Hypomesus olidus \\
Salmo spirinchus Pallas, 1814 & Hypomesus olidus \\
Argentina pretiosa Girard, 1854 & Hypomesus pretiosus \\
Osmerus japonicus Brevoort, 1856 & Hypomesus japonicus \\
Osmerus oligodon Kner, 1865 & Hypomesus japonicus \\
Spirinchus verencundus Jordan and Met», 1913 & Hypomesus japonicus \\
Hypomesus olidus drjagini Taranetz, 1935 & Hypomesus olidus \\
Hypomesus olidus bergi Taranetz, 1935 & Hypomesus olidus \\
Hypomesus sakhalinus Hamada, 1957 & Hypomesus olidus \\
Hypomesus transpacificus nipponensis McAllister, 1963 & Hypomesus nipponensis \\
Hypomesus transpacificus transpacificus McAllister, 1963 & Hypomesus transpacificus \\
Hypomesus chishimaensis new species & Hypomesus chishimaensis \\
\hline
\end{tabular}

\section{Materials and Methods}

Measurements were made with dial calipers to the nearest $0.1 \mathrm{~mm}$. Drawings were made with a camera lucida attached to a binocular microscope. Drawings of the narial filament were made by holding the specimen in position using the larval fish clamp (Saruwatari and Kaneko 1996). Double staining of bone and cartilage was conducted following the protocol of Potthoff (1984). Statistical analyses were conducted with the non-parametric module of STATISTICA for Macintosh. Meristics (Table 2), and measurements expressed as percentage of standard length (SI) or head length (HL) (Tables 3-5), are given as mean values with ranges within parentheses.

Abbreviations of terms used in Tables 3-5: fork length (FL); total length (TL); snout length (SNLG); tip of snout to origin of pelvic fin (SNP2); pelvic fin origin to distal tip of hypural plate (P2CD); tip of snout to origin of dorsal fin (SND); dorsal fin origin to distal tip of hypural plate (DCD); tip of snout to anus (SNAN); anus to distal tip of hypural plate (ANCD); snout to origin of adipose fin (SNAP); adipose fin origin to distal tip of hypural plate (APCD); body depth at origin of dorsal fin (BDD); body depth at anus (BDAN); head depth behind eye (HD); body depth at tip of opercle (BDOP); eye diameter (ED); length of gape of mouth (GAPE); length of pectoral fin (P1LG); length of pelvic fin (P2LG); length of dorsal fin base (DLG); dorsal fin height (DHG); length of anal fin base (ABS); anal fin height (AHG); length of adipose fin base (ADPB); interorbital width (INTOB); head width behind eye (HWBE); snout width (SNW); body width at anus (BWA); body width at dorsal fin origin (BWD); depth of caudal peduncle (DPC).

Material was borrowed from the following institutions: California Academy of Sciences, San Francisco, California (CAS); Museum of Comparative Zoology, Harvard University, Cambridge, Massachusetts (MCZ); Academy of Natural Sciences, Philadelphia, Pennsylvania (ANSP); Field Museum of Natural History, Chicago, Illinois (FMNH); University of Michigan Museum of Zoology, Ann Arbor, Michigan (UMMZ); Cornell University, Ithaca, New York (CU); University of Washington, Seattle, Washington (UW); National Science Museum, Tokyo (NSMT). 


\section{Key to the Species of the Genus Hypomesus}

1A. Mid lateral-line scales 65-68 (59-76); dorsal fin originating anterior to pelvic fin origin; distance from snout to anus more than $75 \%$ of SL; number of pyloric caeca $4-8$, one pair very long

H. japonicus species-group ….. 2

1B. Mid lateral-line scales 55-57 (50-62); dorsal fin originating posterior to pelvic fin origin; distance from snout to anus less than $75 \%$ of SL; number of pyloric caeca $0-6$, none elongate

2A. Dorsal fin originating dorsal to vertebra 31 (30-33); number of pectoral fin rays 15 (13-16); mid lateral-line scales 68 (65-76); transverse scales 19 (15-25)

H. pretiosus

2B. Dorsal fin originating dorsal to vertebra 28 (26-29); number of pectoral fin rays 13 (10-16); mid lateral-line scales 65 (59-69); transverse scales 16 (13-19)

H. japonicus

3A. Nares with well-developed narial septum (Fig. 1A); pneumatic duct extending from behind anterior tip of gas bladder $\cdots H$. olidus species-group $\cdots \cdots H$. olidus

3B. Nares with small narial septum (Fig. 1B); pneumatic duct extending from

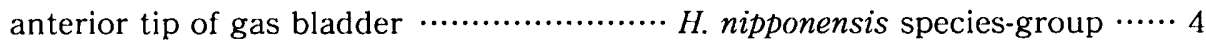

4A. Body without lateral pigmented stripe; pectoral fin rays 11 (10-13); transverse scales 16 (13-19); vomer without posterior extension (Fig. 2C); head depth behind eye $54 \%$ of head length; length of base of adipose fin more than $20 \%$ of head length

H. transpacificus

4B. Body with lateral pigmented stripe running from mid-length to caudal region; pectoral fin rays 11-19; transverse scales 11-18; vomer with posterior extension (Fig. 2A, B); head depth behind eye $50 \%$ of head length; length of base of adipose

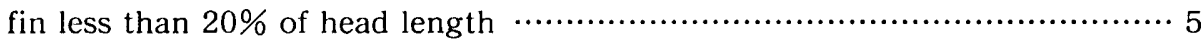

$5 \mathrm{~A}$. Body heavily pigmented; distal central region of glossohyal with irregular patch of small teeth (Fig. 3B); gill rakers on lower arch 19 (16-22); pyloric caeca 2 (0-5); eyes large, diameter more than $7 \%$ of SL $\cdots H$. chishimaensis new species

5B. Body lightly pigmented; distal central region of glossohyal toothless (Fig. 3A); gill rakers on lower arch 23 (20-25); pyloric caeca 4 (1-6); eyes small, diameter less than $7 \%$ of SL

H. nipponensis

\section{Genus Hypomesus Gill}

Hypomesus Gill, 1862a: 15 (type species Argentina pretiosa Girard, 1854: 155, by monotypy); Gill 1862b: 332; Jordan and Evermann 1896: 524; Jordan and Evermann 1902: 225, 230 (key); Hubbs 1925: 51 (key); Berg 1948: 436, 474; Andriyashev 1954: 115-116; Okada 1959: 347; McAllister 1963: 27; Lindberg and Legeza 1965: 96; Kljukanov 1970a: 415; Kljukanov 1970b: 1540.

Mesopus Gill, 1862a: 14 (type species Argentina pretiosa Girard, 1854: 155, by original designation and monotypy; introduced as a proofing error; an objective synonym of Hypomesus Gill; see Jordan 1919: 313; Eschmeyer 1990: 243); Jordan and Snyder 1902: 588.

Diagnosis. A genus of the family Osmeridae distinguished by the following combination of characters: pectoral fin short, less than $20 \%$ of SL, not reaching 


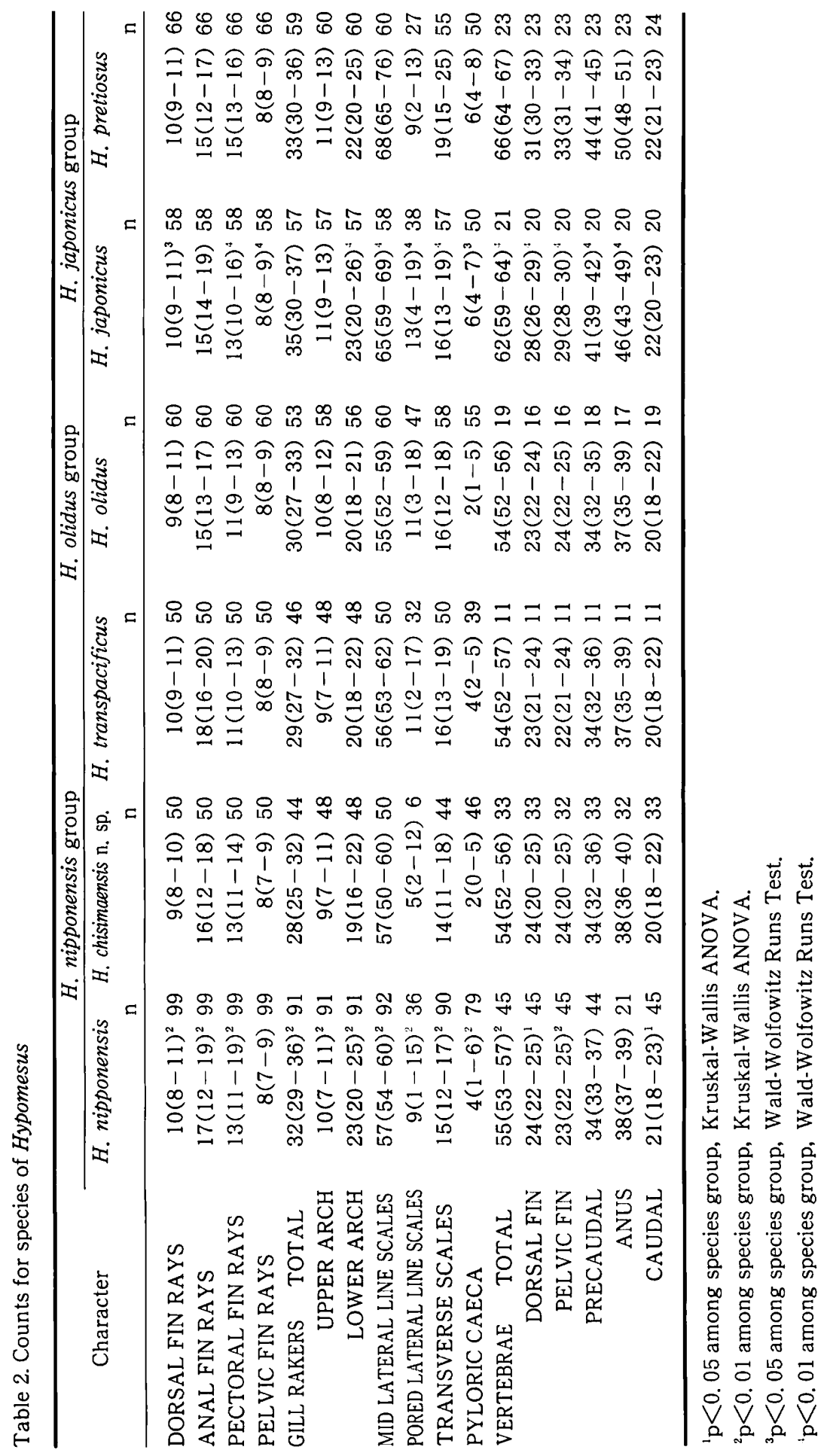


Table 3. Measurements of members of the Hypomesus nipponensis species-group, expressed as percentages of standard length (for abbreviations, see Materials and Methods).

\begin{tabular}{|c|c|c|c|c|c|c|}
\hline & \multirow[t]{2}{*}{ H. nipponensis } & \multicolumn{3}{|c|}{ H. chishimaensis $\mathrm{n} . \mathrm{sp}}$. & \multirow[t]{2}{*}{ H. transpacificus } & \multirow[b]{2}{*}{$\mathrm{n}$} \\
\hline & & $\mathrm{n}$ & & $\mathrm{n}$ & & \\
\hline $\mathrm{FL}$ & $108(106-114)^{1}$ & 87 & $109(105-111)$ & 46 & $109(94-112)$ & 50 \\
\hline $\mathrm{TL}$ & $117(113-120)^{\prime}$ & 67 & $117(113-120)$ & 40 & $119(103-123)$ & 45 \\
\hline $\mathrm{HL}$ & $23(21-26)^{\prime}$ & 88 & $25(22-28)$ & 46 & $23(20-26)$ & 50 \\
\hline SNLG & $7(5-10)^{\prime}$ & 83 & $9(6-12)$ & 45 & $7(5-10)$ & 48 \\
\hline SNP2 & $49(44-54)^{\prime}$ & 87 & $51(48-55)$ & 47 & $49(43-53)$ & 50 \\
\hline $\mathrm{P} 2 \mathrm{CD}$ & $53(49-59)^{\prime}$ & 86 & $50(47-55)$ & 47 & $52(46-54)$ & 50 \\
\hline SND & $50(46-54)^{\prime}$ & 88 & $52(48-57)$ & 47 & $50(41-75)$ & 50 \\
\hline DCD & $51(45-55)^{\prime}$ & 88 & $49(45-53)$ & 47 & $52(45-54)$ & 50 \\
\hline SNAN & $73(68-80)$ & 88 & $73(70-78)$ & 47 & $73(61-76)$ & 50 \\
\hline $\mathrm{ANCD}$ & $29(25-34)^{1}$ & 87 & $28(25-43)$ & 47 & $28(21-31)$ & 50 \\
\hline SNAP & $81(77-88)^{\prime}$ & 87 & $82(79-85)$ & 47 & $80(68-85)$ & 50 \\
\hline APCD & $19(12-25)^{\prime}$ & 86 & $19(17-22)$ & 47 & $21(18-29)$ & 50 \\
\hline BDD & $16(12-19)^{\prime}$ & 87 & $14(9-18)$ & 46 & $17(13-22)$ & 50 \\
\hline BDAN & $12(10-16)^{\prime}$ & 88 & $11(8-17)$ & 46 & $13(11-16)$ & 49 \\
\hline $\mathrm{HD}$ & $12(10-13)^{\prime}$ & 87 & $13(11-22)$ & 46 & $13(11-32)$ & 46 \\
\hline BDOP & $15(13-24)^{\prime}$ & 88 & $15(13-16)$ & 46 & $16(14-34)$ & 50 \\
\hline $\mathrm{ED}$ & $6(5-8)^{\prime}$ & 87 & $8(6-9)$ & 47 & $7(5-9)$ & 50 \\
\hline GAPE & $10(8-11)^{\prime}$ & 88 & $11(9-13)$ & 47 & $9(7-11)$ & 50 \\
\hline PILG & $15(12-19)^{2}$ & 88 & $16(12-32)$ & 46 & $16(14-19)$ & 49 \\
\hline P2LG & $14(12-16)^{\prime}$ & 88 & $14(10-16)$ & 47 & $15(12-18)$ & 49 \\
\hline DLG & $9(7-15)$ & 88 & $8(7-11)$ & 47 & $10(8-12)$ & 50 \\
\hline DHG & $18(16-21)^{\prime}$ & 88 & $17(15-20)$ & 46 & $19(13-22)$ & 47 \\
\hline ABS & $16(13-19)^{\prime}$ & 88 & $15(12-17)$ & 47 & $17(15-35)$ & 50 \\
\hline AHG & $12(7-16)$ & 86 & $12(9-15)$ & 46 & $11(8-13)$ & 50 \\
\hline $\mathrm{ADPB}$ & $4(2-6)^{\prime}$ & 87 & $4(3-6)$ & 47 & $5(4-9)$ & 48 \\
\hline INTOB & $6(4-7)^{\prime}$ & 87 & $6(5-8)$ & 46 & $7(6-8)$ & 50 \\
\hline HWB & $8(5-10)^{1}$ & 87 & $9(7-11)$ & 46 & $9(8-11)$ & 50 \\
\hline SNW & $6(4-18)^{\prime}$ & 87 & $6(5-7)$ & 46 & $6(5-8)$ & 50 \\
\hline BWA & $7(5-12)^{\prime}$ & 87 & $5(4-9)$ & 45 & $6(5-8)$ & 50 \\
\hline BWD & $9(7-16)$ & 86 & $7(5-9)$ & 46 & $9(5-11)$ & 50 \\
\hline DPC & $7(6-11)$ & 88 & $6(5-6)$ & 47 & $7(5-8)$ & 50 \\
\hline
\end{tabular}

${ }^{1} \mathrm{p}<0.01$ among species group, Kruskal-Wallis ANOVA. 
Table 4. Measurements of members of Hypomesus olidus and Hypomesus japonicus speciesgroups, expressed as percentages of standard length (for abbreviations, see Materials and Methods).

\begin{tabular}{|c|c|c|c|c|c|}
\hline & \multirow{3}{*}{$\frac{{ }_{\text {H. olidus group }}}{\text { H. olidus }}$} & \multicolumn{4}{|c|}{ H. japonicus group } \\
\hline & & & H. japonicus & H. pretiosus & \\
\hline & & $\mathrm{n}$ & $\mathrm{n}$ & & $\mathrm{n}$ \\
\hline FL & $110(105-117)$ & 56 & $108(105-129) 50$ & $108(103-110)$ & 49 \\
\hline TL & $118(108-134)$ & 53 & $116(111-120) 46$ & $116(114-120)$ & 48 \\
\hline $\mathrm{HL}$ & $24(21-28)$ & 59 & $22(20-26)^{\prime} 51$ & $21(19-24)$ & 60 \\
\hline SNLG & $7(5-9)$ & 56 & $7(5-10) 51$ & $6(5-9)$ & 53 \\
\hline SNP2 & $50(47-53)$ & 60 & $51(48-54)^{2} 52$ & $53(49-58)$ & 60 \\
\hline $\mathrm{P} 2 \mathrm{CD}$ & $51(31-54)$ & 60 & $50(47-54)^{2} 50$ & $48(26-52)$ & 60 \\
\hline SND & $50(45-52)$ & 60 & $49(47-54)^{2} 52$ & $51(47-54)$ & 60 \\
\hline $\mathrm{DCD}$ & $51(47-55)$ & 60 & $52(48-55)^{2} 51$ & $50(47-52)$ & 60 \\
\hline SNAN & $71(65-76)$ & 60 & $75(72-78) 52$ & $76(70-79)$ & 60 \\
\hline ANCD & $30(26-34)$ & 60 & $26(23-28) 51$ & $26(19-49)$ & 57 \\
\hline SNAP & $79(75-84)$ & 60 & $82(79-84) 51$ & $82(79-85)$ & 58 \\
\hline APCD & $21(17-25)$ & 60 & $19(15-21) 52$ & $19(8-26)$ & 58 \\
\hline $\mathrm{BDD}$ & $18(13-25)$ & 55 & $17(13-21)^{1} 52$ & $16(1-25)$ & 51 \\
\hline BDAN & $13(10-15)$ & 56 & $12(9-14) 52$ & $12(5-25)$ & 60 \\
\hline HD & $12(11-14)$ & 58 & $11(10-13)^{2} 51$ & $10(9-15)$ & 59 \\
\hline BDOP & $16(14-22)$ & 58 & $14(7-16)^{2} 51$ & $14(12-16)$ & 57 \\
\hline $\mathrm{ED}$ & $6(5-9)$ & 59 & $6(4-7)^{2} 52$ & $5(4-6)$ & 58 \\
\hline GAPE & $9(6-10)$ & 60 & $8(7-10) 50$ & $8(6-9)$ & 57 \\
\hline P1LG & $18(13-22)$ & 60 & $15(7-17)^{2} 51$ & $14(12-15)$ & 58 \\
\hline P2LG & $16(13-19)$ & 59 & $13(4-16)^{2} 52$ & $12(9-14)$ & 59 \\
\hline DLG & $10(8-14)$ & 59 & $9(8-13)^{2} 52$ & $9(7-10)$ & 58 \\
\hline DHG & $19(15-26)$ & 59 & $16(10-18)^{2} 52$ & $14(12-17)$ & 58 \\
\hline $\mathrm{ABS}$ & $15(12-18)$ & 59 & $13(11-15)^{2} 52$ & $12(10-14)$ & 59 \\
\hline $\mathrm{AHG}$ & $12(8-16)$ & 60 & $9(2-17)^{\prime} 52$ & $8(6-10)$ & 59 \\
\hline $\mathrm{ADPB}$ & $6(4-8)$ & 60 & $3(2-5)^{2} 52$ & $3(2-5)$ & 56 \\
\hline INTOB & $6(5-8)$ & 57 & $6(5-7)^{2} 52$ & $5(5-6)$ & 59 \\
\hline HWB & $9(7-15)$ & 58 & $8(6-10)^{2} 52$ & $8(5-17)$ & 58 \\
\hline SNW & $6(5-7)$ & 57 & $6(4-9)^{2} 51$ & $5(3-8)$ & 59 \\
\hline BWA & $7(4-11)$ & 57 & $8(6-13)^{2} 52$ & $7(5-9)$ & 59 \\
\hline BWD & $10(6-12)$ & 57 & $10(3-19)^{2} 48$ & $9(6-16)$ & 49 \\
\hline DPC & $7(5-8)$ & 58 & $7(5-8) 52$ & $7(6-8)$ & 59 \\
\hline
\end{tabular}

' $p<0.05$ among species group, Wald-Wolfowit\% Runs Test. ${ }^{2} \mathrm{p}<0.01$ among species group, Wald-Wolfowitz Runs Test. 


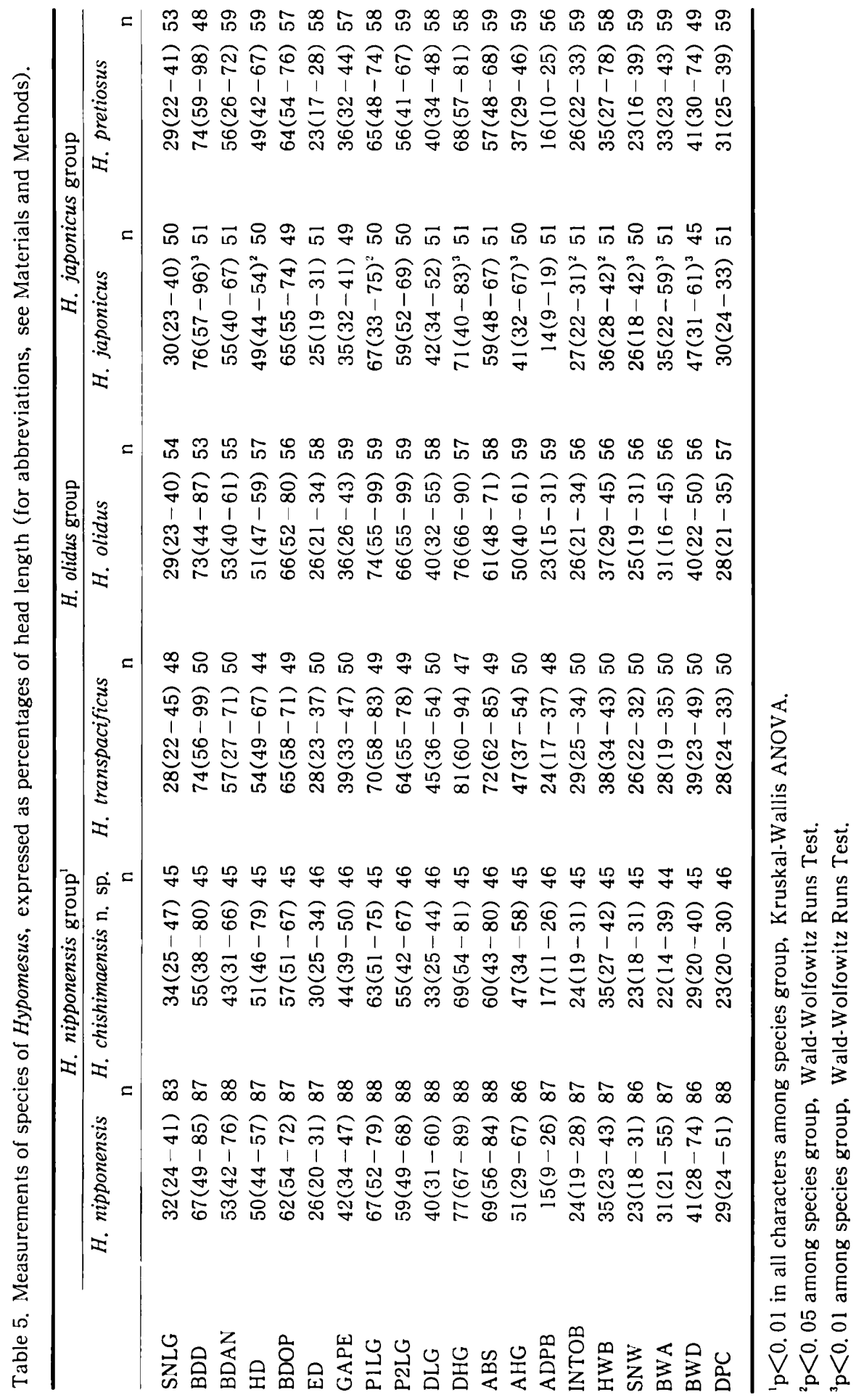



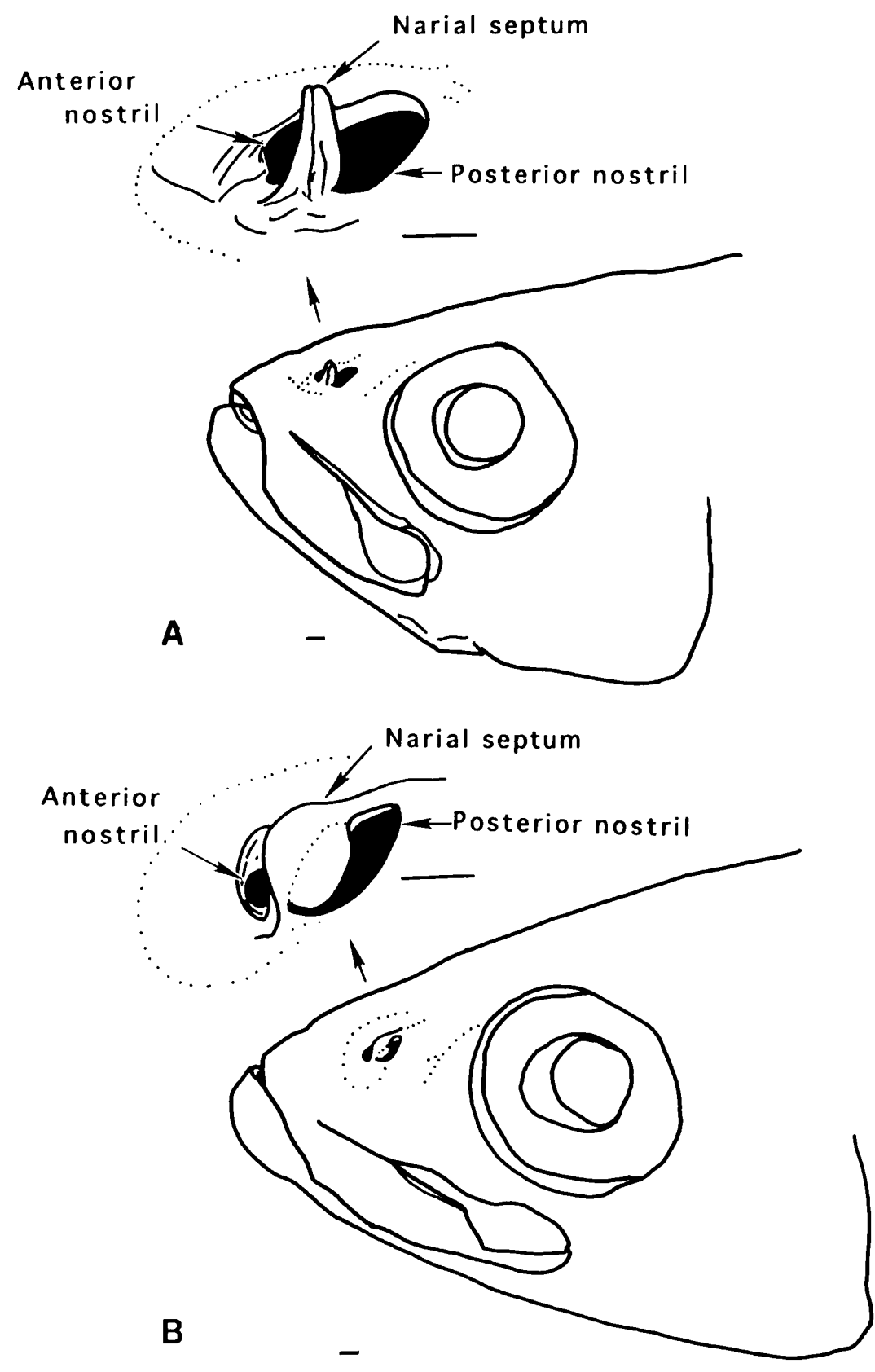

Fig. 1. Narial septum of species of Hypomesus: A, H. olidus, UW 27732,78.2mm SL; H. nipponensis, NSMT-P 49932, 93.7mm SL. Bars indicate $0.5 \mathrm{~mm}$. 

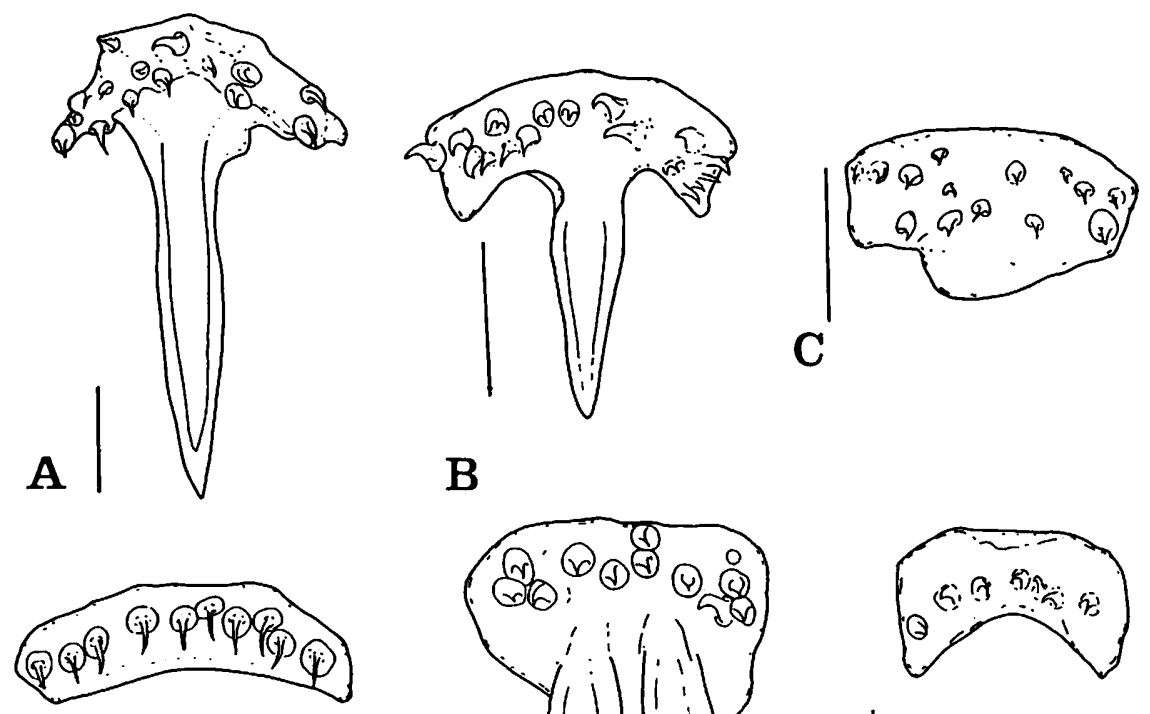

B
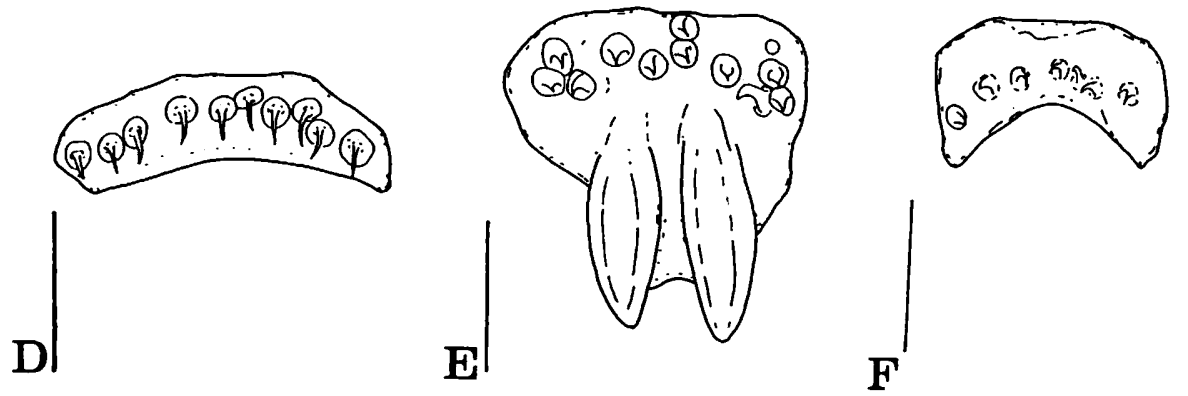

Fig. 2. Vomer of species of the genus Hypomesus. A, H. nipponensis, UW 29656; B, $H$. chishimaensis, UW 29161; C, H. transpacificus, CAS 82275; D, H. olidus, UW 27732; E, H. japonicus, UW 27617; F, H. pretiosus, UW 4667. Bar indicates $0.5 \mathrm{~mm}$.

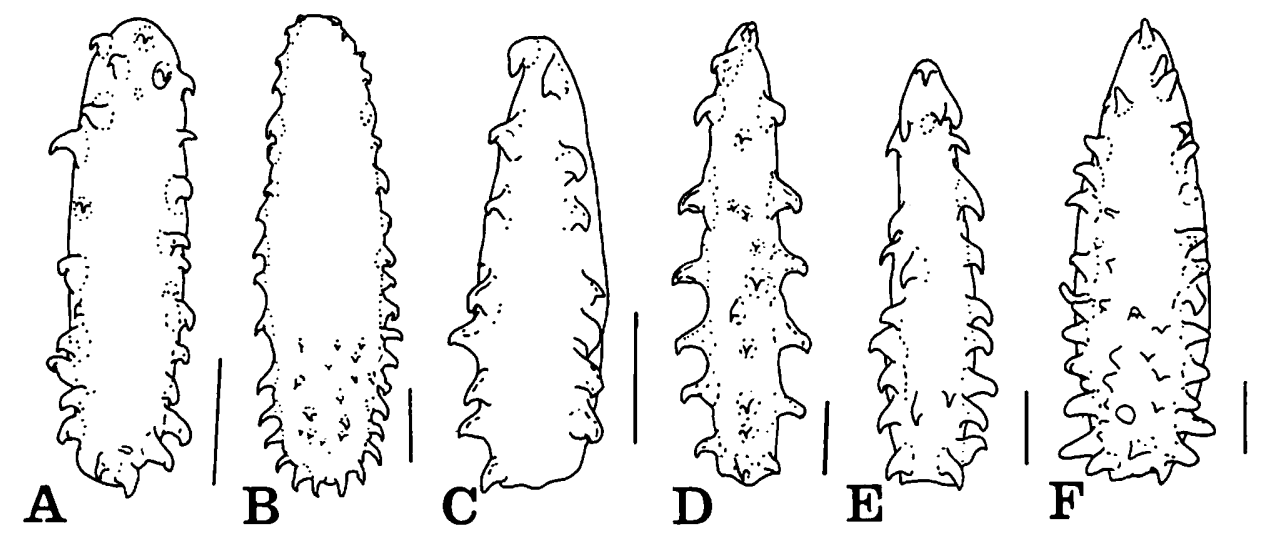

Fig. 3. Glossohyal bones of species of the genus Hypomesus. A, H. nipponensis, UW 29656; B, $H$. chishimaensis, UW 29161; C, H. transpacificus, CAS 82275; D, H. olidus, UW 27732; E, H. japonicus, UW 27617; F, H. pretiosus, UW 4667. Bar indicates $0.5 \mathrm{~mm}$. 
dorsal fin origin; lateral-line incomplete, not reaching dorsal fin origin; upper jaw short, posterior tip of maxilla not extending beyond posterior margin of lens of eye; opercle and subopercle smooth, without striae; teeth on glossohyal small and weak.

Description. Body elongate, slender, slightly compressed; dorsal and pelvic fins located mid-body; anal fin base $12-35 \%$ of SL; caudal fin bifurcate, ventral lobe slightly longer than dorsal lobe; all fins lightly pigmented; adipose fin present; anal fin base of mature males without process; mouth small, terminal, or only slightly directed dorsally; gas bladder present; gill rakers with smooth surface; pseudobranch present; peritoneum silvery, speckled with dark pigmentation; scales cycloid.

\section{Hypomesus nipponensis species-group}

Diagnosis. Nares with small narial septum (Fig. 1B); pneumatic duct extending from anteriormost tip of gas bladder, dorsal fin originating posterior to pelvic fin origin; pyloric caeca 2-4 (0-6), all about equal in length; mid lateral-line scales 56-57 (50-62); cephalic sensory pores moderate in size.

\section{Hypomesus nipponensis McAllister, 1963 Japanese name: Wakasagi}

(Fig. 4A)

Hypomesus olidus- Jordan and Evermann 1896: 231 (partim); Hubbs 1925: 51 (key) (partim); Schmidt 1950: 33(partim); Andriyashev 1954: 116-117(partim); Hamada 1954: 260 (key) (partim); Okada 1959: 347, fig. 54; Hamada 1961:13-39. Mesopus olidus- Jordan and Snyder 1902: 588 (partim; Aomori and Matsushima, Japan).

Hypomesus transpacificus nipponensis- McAllister 1963: 36, fig. 11 (NMC60-498-A; Lake Onuma, Hokkaido, Japan)

Hypomesus nipponensis- Kljukanov 1970a: 415; Kljukanov 1970b: 1541 (key); Gritzenko and Churikov 1983: 553 (key); Masuda et al. 1984: 33, pl. 36F.

Material examined. ANSP 85447,3 specimens, $62.8-74.7 \mathrm{~mm}$ SL, Japan. CAS 82279, 10 specimens, 85.1-98.0mm SL, Lake Shastina, California, USA; CAS 106775, 10 specimens, $80.1 \cdot 101.5 \mathrm{~mm}$ SL, Aomori, Japan; CAS 123537, 3 specimens, 70.6$110.6 \mathrm{~mm}$ SL, Lake Kawaguchi, Yamanashi, Japan. FMNH 58695, 12 specimens, 70.2-79.0mm SL, Aomori, Japan. NSMT-P 49932, 1 specimen, $194.5 \mathrm{~mm}$ SL, Lake Hinuma, Ibaraki, Japan. UMMZ 61245, 10 specimens, 64.4-84.6mm SI., Japan; UMMZ 179973, 2 specimens, 57.9-58.6mm SL, Lake Onuma, Iokkaido, Japan (paratypes of H. transpacificus nipponensis); UMMZ 178878, 1 specimen, $50.4 \mathrm{~mm}$ SI, Mutsu Bay, at Asamushi and Kukurisaka, Japan. UW 11708, 6 specimens, 96.7-124.5mm SL, Lake Biwa, Japan; UW 26554, 10 specimens, 100.2-112.3mm SL, Lake Hinuma, Ibaraki, Japan; UW 27620, 7 specimens, 63.4-74.7mm SL, Lake Abashiri, Hokkaido, Japan; UW 29656, 16 specimens, 83.8-112.7mm SL, Lake Kitaura, Ibaraki, Japan.

Diagnosis. Vomer T-shaped with well-developed posterior process (Fig. 2A); periphery of glossohyal bone with single row of conical teeth, central part toothless (Fig. 3A); gill rakers $10(7-11)+23(20-25)=32(29-36)$; vertebrae $34(33-37)+21$ 

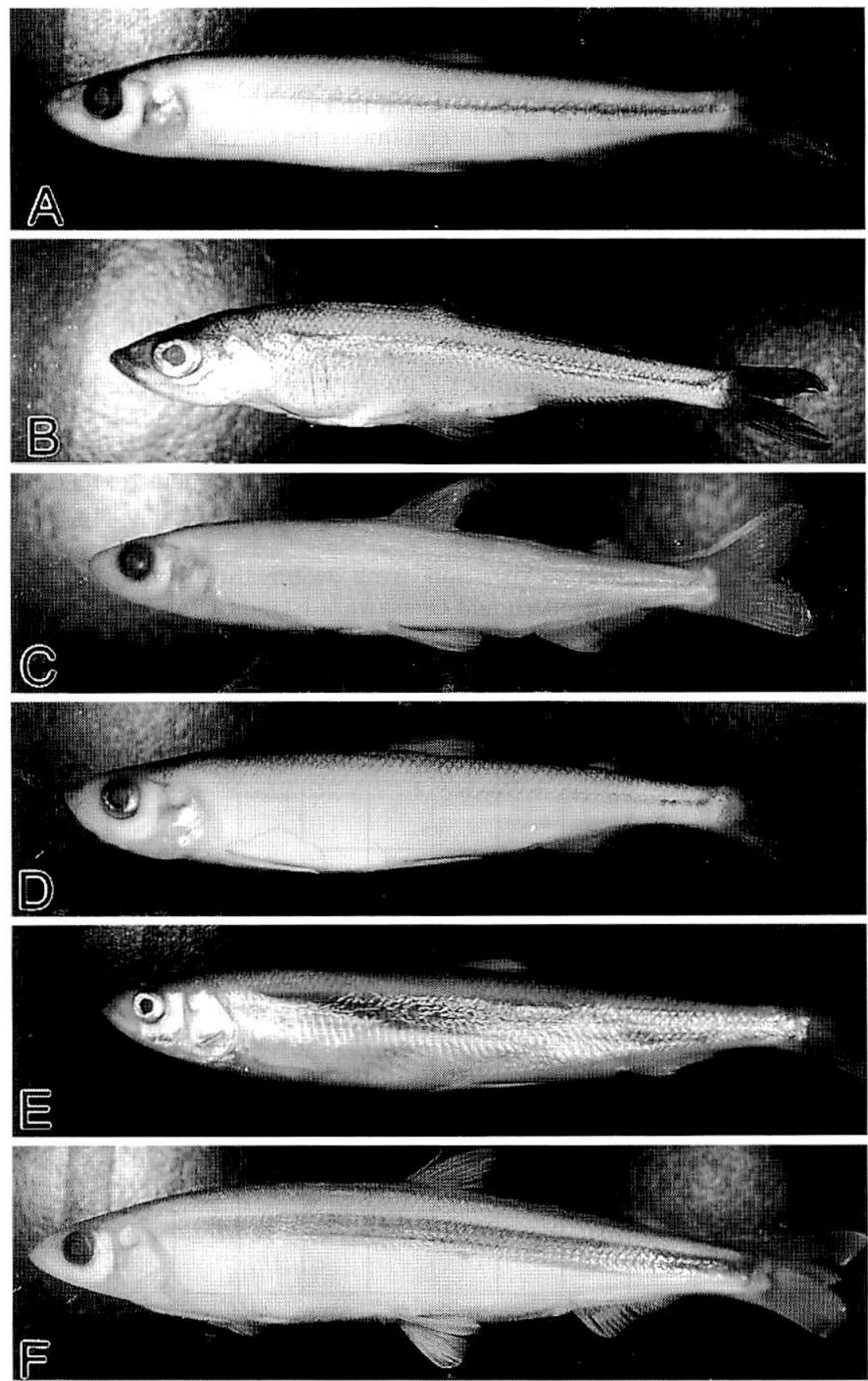

Fig. 4. Species of the genus Hypomesus. A, H. nipponensis, UW 27076, $87 \mathrm{~mm} \mathrm{SL;} \mathrm{B,} H$. chishimaensis, new species, holotype, UW 41700, 64mm SL; C, H. transpacificus, CAS 82275 , $65 \mathrm{~mm}$ SL; D, H. olidus, UW 27732, $77 \mathrm{~mm}$ SL; E, H. japonicus, UW 40201, 129mm SL; F, $H$. pretiosus, UW 5103, $110 \mathrm{~mm} \mathrm{SL}$. 
$(18-23)=55(53-57) ;$ pyloric caeca 4 (1-6); base of adipose fin less than $20 \%$ of head length; eye large, diameter 26 (20-31)\% of HL; adipose eyelid absent; other characters as for $H$. nipponensis species-group.

Description. Dorsal fin rays 10 (8-11); anal fin rays 17 (12-19); pectoral fin rays 13 (11-19); pelvic fin rays 8 (7-9); mid lateral-line scales 57 (54-60); transverse scales 15 (12-17); dorsal fin originating dorsal to vertebra 24 (22-25); pelvic fin originating ventral to vertebra 23 (22-25); anus located ventral to vertebra 38 (37-39) (Table 2).

Head length 23 (21-26)\% of SL, depth 50 (44-57)\% of HL; snout length 32 (24-41)\% of HL, width 23 (18-31)\% of HL; gape of mouth 42 (34-47)\% of HL; interorbital region slightly elevated, dorsal margin of eye located below dorsal margin of head; interorbital width 24 (19-28)\% of HL; body depth at opercle 62 (54-72)\% of HL; snout to dorsal fin origin 50 (46-54)\% of SL; snout to pelvic fin origin 49 (44-54)\% of SL; snout to anus 73 (68-80)\% of SL; depth of caudal peduncle 29 (24-51)\% of HL. For additional proportional data, see Tables 3-5.

Color after preservation. Light beige overall, dorsal surface somewhat darker than ventral; light brown lateral stripe, silvery in some specimens, extending from mid-body to caudal peduncle; posterior tip of lower jaw pigmented; posterior margin of dorsal scales lightly pigmented.

Distribution. Found in brackish and fresh water throughout the Japanese Archipelago, except for the Ryukyu and Ogasawara Islands (Fig. 5). Small populations are present in various lakes in California, originating from artificial transplantation of eggs in 1959, at a time when $H$. nipponensis and $H$. transpacificus were thought

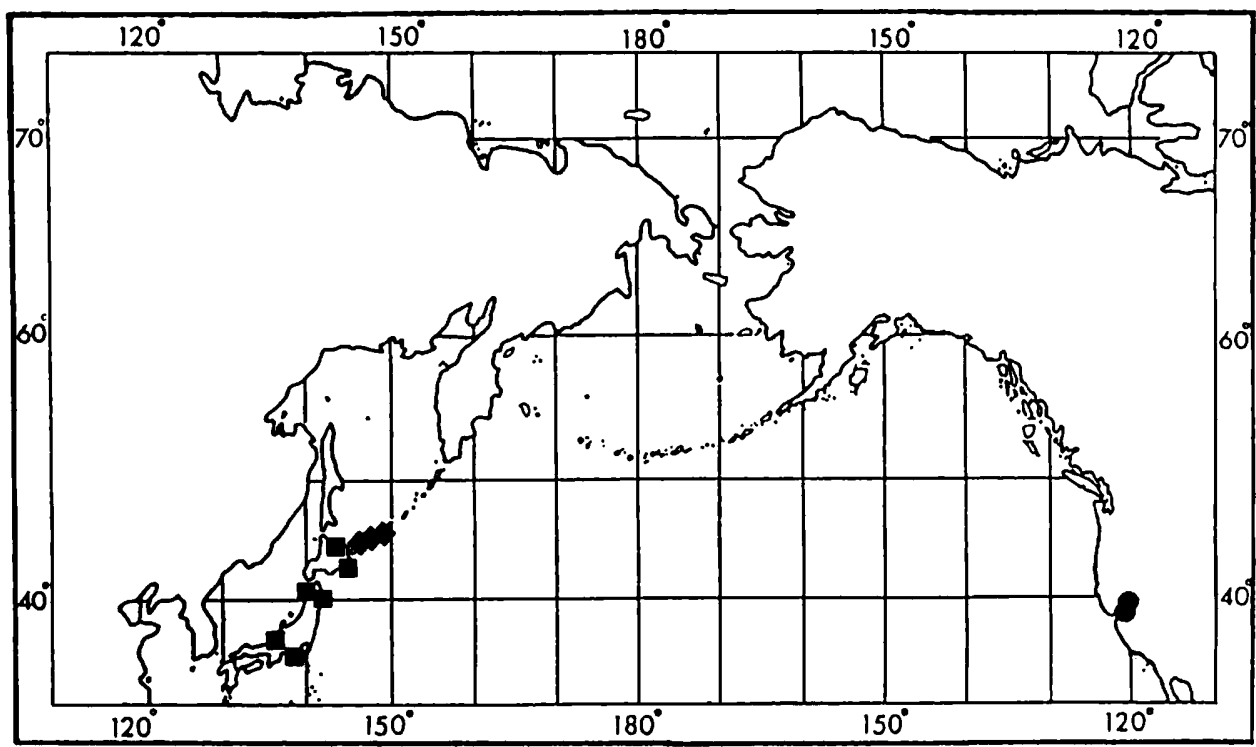

Fig. 5. Geographic distribution of examined material of members of the Hypomesus nipponensis species-group: H. nipponensis ( $\boldsymbol{\square})$, known from throughout the Japanese Archipelago (except for the Ryukyu and Ogasawara Islands), and small introduced populations in California (see Wales 1962); H. chishimaensis ( $\diamond$ ), restricted to the southern Kuril Islands; and H. transpacificus (•), restricted to the Sacramento-San Joaquin Estuary, California, USA. 
to be conspecific (see Wales 1962).

Life history. Hypomesus nipponensis is the most common osmerid in Japan. Although widely thought of as a freshwater fish, it is (together with Salangichthys microdon) primarily a brackish-water species (Saruwatari and Okiyama 1992). This misconception finds its root in the widespread transplantation of eggs throughout bodies of freshwater in Japan.

Spawning takes place in the spring. In mainland Honshu, Japan, most individuals mature and spawn in their first year. Post-spawning mortality is almost $100 \%$ (Sato 1952, 1953; Katayama and Kawasaki 1994; Katayama and Okata 1995; Katayama et al. 1996). In Hokkaido, some individuals do not mature until year two or even later.

Comments. See those for $H$. olidus.

\author{
Hypomesus chishimaensis, new species \\ Japanese name: Chishima Wakasagi, new \\ English name: Kunashir Smelt, new
}

(Fig. 4B)

Holotype. UW 41700, 64mm SL, Lake Aliger, Kunashir Island, Kuril Islands, $44^{\circ} 02^{\prime} 48^{\prime \prime} \mathrm{N}, 145^{\circ} 44^{\prime} 24^{\prime \prime E}, 31$ July 1994.

Paratypes. UW 29161, 57 specimens, 48.5-94.5mm SL, Lake Kuibyshevskoye, Iturup Island, Kuril Islands, 22 August 1994; UW 29239, 4 specimens, 48.7-68.5mm SL, Lake Sopochnoye, Iturup Island, Kuril Islands, $45^{\circ} 19^{\prime} 24^{\prime \prime} \mathrm{N}, 148^{\circ} 25^{\prime} 06^{\prime \prime} \mathrm{E}, 19$ August 1994; UW 29253, 5 specimens, 58.5-80.1mm SL, Lake Kuibyshevskoye, Iturup Island, Kuril Islands, $45^{\circ} 4^{\prime} 42^{\prime \prime} \mathrm{N}, 147^{\circ} 39^{\prime} 12^{\prime \prime} \mathrm{E}, 22$ August 1994; UW 29256, 7 specimens, 49.4-78.0mm SL, Lake Aliger, Kunashir Island, Kuril Islands, $44^{\circ} 02^{\prime} 48^{\prime \prime} \mathrm{N}$, $145^{\circ} 44^{\prime 2} 2$ "E, 31 July 1994; UW 29264, 1 specimen, 69.2mm SL, stream between Lake Bezymyannoye and Lake Lagunnoye, Kunashir Island, Kuril Islands, $44^{\circ} 03^{\prime} 00^{\prime \prime} \mathrm{N}, 1$ $45^{\circ} 45^{\prime} 49^{\prime \prime} \mathrm{E}, 31$ July 1994 .

Diagnosis. Vomer T-shaped, with posterior process (Fig. 2B); periphery of glossohyal bone with a single row of conical teeth, and an irregular patch of similar teeth at center of distal portion (Fig. 3B); gill rakers $9(7-11)+19(16-22)=28$ $(25-32)$; vertebrae $34(32-36)+20(18-22)=54(52-56)$; pyloric caeca $2(0-5)$; base of adipose fin less than $20 \%$ of head length; eye large, diameter $30(25-34) \%$ of HL; adipose eyelid absent; other characters as for $H$. nipponensis species-group.

Description. Dorsal fin rays 9 (8-10); anal fin rays 16 (12-18); pectoral fin rays 13 (11-14); pelvic fin rays 8 (7-9); mid lateral-line scales 57 (50-60); transverse scales 14 (11-18); dorsal fin originating dorsal to vertebra 24 (20-25); pelvic fin originating ventral to vertebra 24 (20-25); anus located ventral to vertebra 38 (36-40) (Table 2).

Head large, length 25 (22-28)\% of SL, depth 51 (46-79) of HL; snout relatively narrow and pointed, length 34 (25-47)\% of HL, width 23 (18-31)\% of IIL; gape of mouth 44 (39-50)\% of HL; interorbital region flat, dorsal margin of eye almost flush with dorsal margin of head; interorbital width 24 (19-31)\% of HL; body depth at opercle 57 (51-67)\% of HL; snout to dorsal fin origin 52 (48-57)\% of SL; snout to pelvic fin origin 51 (48-55)\% of SL; snout to anus 73 (70-78)\% of SL; depth of caudal peduncle 23 (20-30)\% of HL. For additional proportional data, see Tables 3-5.

Color after preservation. Body light beige ventrally, moderate to darkly pigmented dorsally; dorso-cephalic region black in some individuals; body with 
strong, silvery lateral stripe; posterior tip of lower jaw heavily pigmented; anterior half of upper jaw pigmented.

Distribution. Known only from southernmost islands of the Kuril Island chain: Kunashir, Iturup, and Zelionyi (Fig. 5).

Life history. Unknown.

Etymology. The name chishimaensis is derived from the Japanese name for the Kuril Islands, Chishima Islands, the type locality.

Comments. By unfortunate oversight, the name Hypomesus chishimaensis appeared in conjunction with a diagnosis distinguishing it from its congeners in the abstracts of the 1996 Annual Meeting of the American Society of Ichthyologists and Herpetologists (Saruwatari et al. 1996). While some might recognize new species descriptions that appear in abstracts as constituting valid publication, we follow $\mathrm{W}$. N. Eschmeyer and C. J. Ferraris, Jr. (personal communication, 25 September 1996) in viewing abstracts in light of Art. 8(a)(1), which states that a publication

"must be issued publicly for the purpose of providng a permanent scientific record" [ICZN, 1985:13]. We don't think abstracts of meetings, issued in advance, serve that function. This seems especially true now, when there is often little similarity between statements in the abstract and that which is presented orally. This is in contrast to summaries of meetings published after the fact...."

With specific reference to $H$. chishimaensis, Eschmeyer and Ferraris (personal communication, 20 January 1997) stated further: "Abstracts of this society [American Society of Ichthyologists and Herpetologists] are generally not considered part of the permanent scientific record and are rarely subsequently cited; we regard the name as not available, not in a work issued for the purpose of providing a permanent scientific record." On this basis, the diagnosis and description provided herein constitute the original description.

For additional comments, see those for $H$. olidus.

Hypomesus transpacificus McAllister, 1963

English name: Delta Smelt

(Fig. 4C)

Hypomesus olidus- Jordan and Evermann 1896: 231 (partim); Hubbs 1925: 51 (key) (partim).

Hypomesus transpacificus transpacificus- McAllister 1963: 34, fig. 11 (NMC60-499; San Joaquin River, California, USA).

Hypomesus transpacificus- Kljukanov 1970a: 415; Kljukanov 1970b: 1541 (key); Gritzenko and Churikov, 1983: 553 (key).

Material examined. CAS 30865, 1 specimen, $58.9 \mathrm{~mm}$ SL, Delta Mendota Canal, San Joaquin, California, 13 December 1973; CAS 32393, 10 specimens, $57.5-69.8 \mathrm{~mm}$ SL, Delta Mendota Canal, California, 20 October 1972; CAS 59288, 10 specimens, 47.9-59.2mm SL, Sacramento River drainage, San Joaquin River near Antioch, Contra Costa County, California, January 1947; CAS 76649, 5 specimens, 51.3-56.3mm SL, Sacramento River, California, 31 December 1991; CAS 82282, 1 specimen, $77.6 \mathrm{~mm}$ SL, Calaverosa River, California, 29 March 1957; CAS 82284, 1 specimen, 66.0mm SL, 
California, 17 June 1942; CAS 82285, 4 specimens, 57.3-74.5mm SL, South Fork, Mokelujne River, California, 25 January 1949; CAS 82286, 1 specimen, 79.6mm SL, San Joaquin River, California, 8 August 1947; CAS 82287, 3 specimens, 57.5-65.7mm SL, Antioch, San Joaquin River, California, 16 December 1947; CAS 82288, 1 specimen, $69.9 \mathrm{~mm}$ SL, Carquinez Strait, Contra Costa County, California, 10 January 1940; CAS 82289, 1 specimen, 75.9mm SL, California, 14 June 1947; CAS 82291, 3 specimens, 38.8-53.0mm SL, California, I November 1946. CU 35072, 9 specimens, 67.0-78.8mm SL, Sacramento River, Freeport, California, 16 April 1957.

Diagnosis. Vomer without posterior process (Fig. 2C); periphery of glossohyal bone with single row of conical teeth, central part toothless (Fig. 3C); gill rakers 9 $(7-11)+20(18-22)=29(27-32)$; vertebrae $34(32-36)+20(18-22)=54(52-57)$; pyloric caeca 4 (2-5); base of adipose fin more than $20 \%$ of head length; eye large, diameter 28 (23-37)\% of HL; adipose eyelid poorly developed; other characters as for $H$. nipponensis species-group.

Description. Dorsal fin rays 10 (9-11); anal fin rays 18 (16-20); pectoral fin rays 11 (10-13); pelvic fin rays 8 (8-9); mid lateral-line scales 56 (53-62); transverse scales 16 (13-19); dorsal fin originating dorsal to vertebra 23 (21-24); pelvic fin originating ventral to vertebra 22 (21-24); anus located ventral to vertebra 37 (35-39) (Table 2).

Head length 23 (20-26)\% of SL, depth 54 (49-67)\% of HL; snout short and rounded, length 28 (22-45)\% of HL, width 26 (22-32)\% of HL; gape of mouth 39 (33-47)\% of SL; interorbital region convex, dorsal margin of eye below dorsal margin of head; interorbital width 29 (25-34)\% of HL; body depth at opercle 65 (58-71)\% of $\mathrm{HL}$; snout to dorsal fin origin 50 (41-75)\% of SL; snout to pelvic fin origin 49 (43-53)\% of SL; snout to anus $73(65-76) \%$ of SL; depth of caudal peduncle 28 (24-33)\% of HL. For additional proportional data, see Tables 3-5.

Color after preservation. Body light beige overall, without lateral stripe; maxilla unpigmented, premaxilla pigmented.

Distribution. Restricted to brackish and fresh waters of the Sacramento and San Joaquin river systems, California, USA (Fig. 5).

Comments. See those for H. olidus.

Life history. Moyle and Herbold (1992) gave a detailed account of the life history of $H$. transpacificus. Spawning occurs from late February through May. Eggs are demersal. The diet consists of zooplankton. Maturation is attained at $55-70 \mathrm{~mm}$ fork length, and post spawning mortality is $100 \%$.

\section{Hypomesus olidus species-group}

Diagnosis. Nares with well-developed narial septum (Fig. 1A); pneumatic duct connected posterior to anteriormost tip of gas bladder; alignment of origin of dorsal and pelvic fins variable; pyloric caeca 2 (1-5), all about equal in length; mid lateralline scales 55 (52-59); cephalic sensory pores large.

Hypomesus olidus (Pallas, 1814) Japanese name: Ishikariwakasagi English name: Pond Smelt

(Fig. 4D) 
Salmo olidus- Pallas 1814: 391 (type specimen unknown; rivers and lakes of Kamchatka, Kamchatka River, Russia; date established by Opinion 212, International Commission on Zoological Nomenclature.).

Salmo spirinchus- Pallas 1814: 387 (partim; rivers of Kamchatka,).

Hypomesus olidus- Turner 1886: 103; Jordan and Evermann 1896: 525, pl. 87, fig. 231 (partim;Alaska and Kamchatka); Jordan and Evermann 1902: 231(partim); Evermann and Goldsborough 1907:270; Hubbs 1925: 51 (key)(partim); Berg 1948: 475; Schmidt 1950: 33(partim); Andriyashev 1954: 116(partim); Wilimovsky 1954: 282; McAllister 1963: 31, fig. 10; Lindberg and Legeza 1965: 100, fig. 120 (southern Kuril Islands, Sakhalin, mouth of Amur River, Maritime Territory, Russia); Kljukanov 1970a: 415; Kljukanov 1970b: 1540 (key); Gritzenko and Churikov 1983: 553 (key); Masuda et al. 1984: 33, pl. 36G.

Mesopus olidus- Jordan and Snyder 1902: 588 (partim; Grantley Harbor and Port Clarance, Alaska, USA).

Hypomesus japonicus- Hubbs 1925: 51 (key) (partim).

Hypomesus olidus drjagini- Taranetz 1935: 85 (type locality, small lake on lower course of Tym River, Sakhalin, Russia; figured).

Hypomesus olidus bergi- Taranetz 1935: 85 (type locality, basin of River Kolyma, Siberia, Russia); Berg 1948: 477.

Hypomesus sakhalinus- Hamada 1957: 136, fig. 1 (type locality, Lake Tarakai, Sakhalin, Russia); Hamada 1961: 13-39.

Material examined. CAS 82283,1 specimen, 91.8mm SL, Grantley Harbor, Alaska; CAS 129507, 5 specimens, 53.7-76.9mm SL, Chignik River, Alaska, June 1929. MCZ 34244, 5 specimens, 42.2-47.5mm SL, lake in basin of Tym River, Sakhalin, Russia, 1934; MCZ 101562, 1 specimen, 95.3mm SL, estuary of Bol'shaya River, SW Kamchatka, Russia, May 1990; MCZ 101562, 6 specimens, 89.5-114.5mm SL, estuary of Bol'shaya River, Kamchatka, Russia, May 1990. UW 2350, 10 specimens, 66.681.2mm SL, Lake Iliamna, Alaska, 14 May 1932; UW 2351, 1 specimen, $69.0 \mathrm{~mm} \mathrm{SL}$, Naknek River, Alaska, 19 May 1932; UW 11268, 3 specimens, 75.6-89.5mm SL, Kushokwin River, Bethel, Alaska, 19 May 1955; UW 11269, 1 specimen, 67.7mm SL, Egegik River, Alaska; UW 16937, 7 specimens, 46.6-86.8mm SL, Naknek River, Alaska, July 1950; UW 16945, 4 specimens, 53.4-60.7mm SL, Lake Nerka, Alaska, 10 January 1964; UW 27504, 4 specimens, 89.4-100.5mm SL, Bering Sea, north of St. Lawrence Island, 18 January 1976; UW 27508, 1 specimen, 88.5-93.9mm SL, Port Clarence, Alaska, 17 September 1976; UW 27732, 5 specimens, 74.4-81.2mm SL, Lake Toro, Hokkaido, Japan.

Diagnosis. Vomer without posterior process (Fig. 2D); periphery of glossohyal bone with single row of conical teeth, another row of smaller teeth in center (Fig. $3 \mathrm{D})$; gill rakers $10(8-12)+20(18-21)=30(27-33)$; vertebrae $34(32-35)+20(18$ $22)=54(52-56)$; pyloric caeca $2(1-5)$; base of adipose fin more than $20 \%$ of HL; eye diameter 26 (21-34)\% of HL; adipose eyelid absent; other characters as for $H$. olidus species-group.

Description. Dorsal fin rays 9 (8-11); anal fin rays 15 (13-17); pectoral fin rays 11 (9-13); pelvic fin rays 8 (8-9); mid lateral-line scales 55 (52-59); transverse scales 16 (12-18); dorsal fin originating dorsal to vertebra 23 (22-24); pelvic fin originating ventral to vertebra 24 (22-25); anus located ventral to vertebra 37 (35-39) (Table 2).

Head length $24(21-28) \%$ of SL, depth 51 (47-59)\% of HL; snout short and 
round, length 25 (19-31)\% of HL, width 25 (19-31)\% of HL; gape of mouth 36 (26-43)\% of HL; interorbital region slightly convex, dorsal margin of eye located slightly below dorsal margin of head; interorbital width 26 (21-34)\% of HL; body depth at opercle 66 (52-80)\% of HL; snout to dorsal fin origin 50 (45-52)\% of SL; snout to pelvic fin origin 50 (47-53)\% of SL; snout to anus 71 (65-76)\% of SL; depth of caudal peduncle $28(21-35) \%$ of HL. For additional proportional data, see Tables 3-5.

Well-developed nuptial tubercles present in mature males during spawning season.

Color after preservation. Light tan to beige, darker dorsally above midline. Some specimens with weak lateral stripe running length of body.

Distribution. Hokkaido, Japan, to Kamchatka and across the North Pacific to Alaska (Fig. 6).

Life history. A land-locked population is present in Hokkaido, Japan. In other localities, the species is basically anadromous, ascending rivers to spawn in the spring (Hamada 1961).

Comments. Counts and proportional measurements of members of the $H$. nipponensis and $H$. olidus groups overlap greatly among species. Because of this large overlap, and until Hamada (1957) described $H$. sakhalinus ( $=H$. olidus), the name $H$. olidus encompassed four of the six species recognized in the present study. Later, McAllister (1963), while synonymizing $H$. sakhalinus with $H$. olidus, split the latter into three species and four new subspecies: H. olidus, H. transpacificus transpacificus,

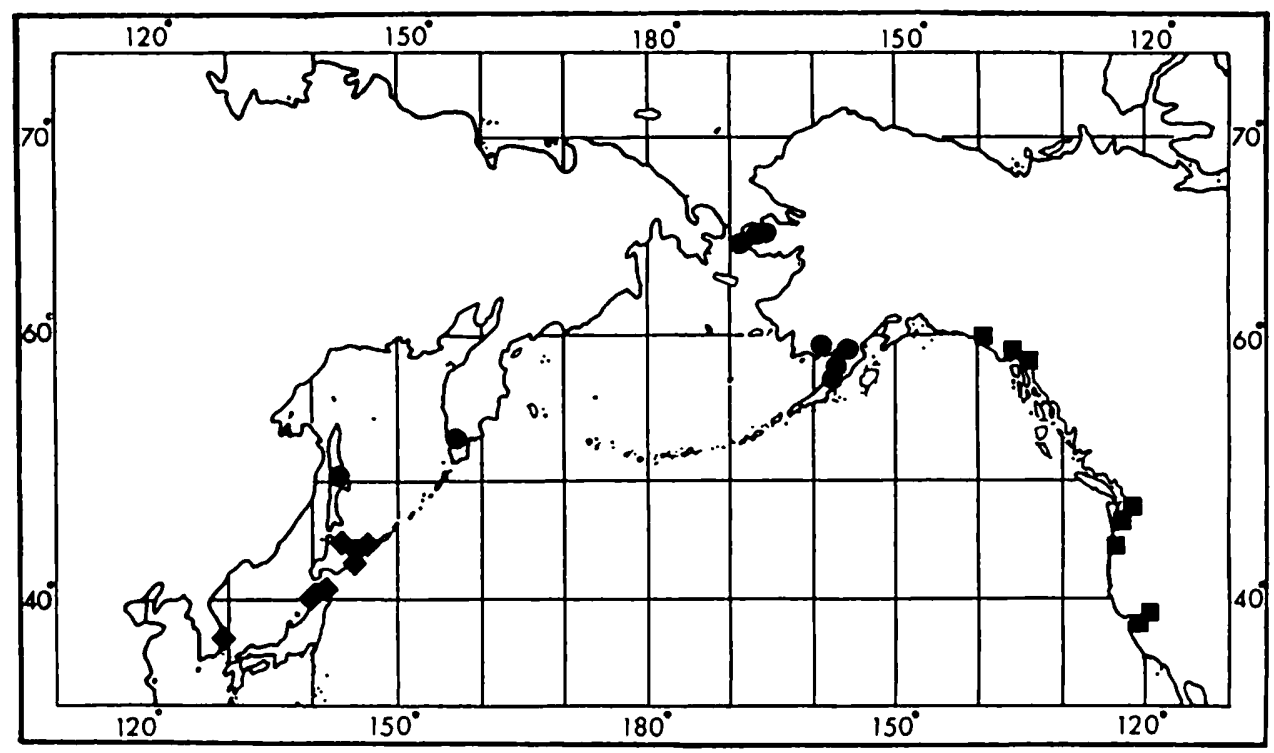

Fig. 6. Geographic distribution of examined material of Hypomesus olidus ( $)$, known from Hokkaido, Japan, to Kamchatka and across the North Pacific to Alaska; and members of the $H$. japonicus species-group: H. japonicus ( $\diamond)$, from the Pacific coast of Japan to Peter the Great Bay. Russia; and H. pretiosus ( $\square$ ). Pacific coast of North America from Long Beach, California, to Prince William Sound, Alaska. 
$H$. transpacificus nipponensis, $H$. pretiosus pretiosus, and $H$. pretiosus japonicus. Kljukanov (1970a, b) later elevated these subspecies to full species rank based on osteological characters. In the present study, Kljukanov's (1970a, b) conclusions are supported (see Table 1).

Counts of the species in the $H$. nipponensis and $H$. olidus groups overlap significantly and the best character distinguishing $H$. olidus from its congeners in the $H$. nipponensis species-group is the attachment of the pneumatic duct to the gas bladder. However, prior to the work of Hamada (1957), the significance of this character was not recognized. Therefore, because many of the type specimens have been lost, determining accurate synonymies is almost impossible. However, based on the museum-preserved specimens examined in the present study, it has become clear that the distribution of the species is primarily allopatric, with very little overlap between $H$. olidus and the members of the $H$. nipponensis species-group. Hypomesus nipponensis is confined to the Japanese Archipelago and is not found further north. Hypomesus chishimaensis is confined to the southern Kuril Islands. Hypomesus transpacificus is confined to the lower Sacramento and San Joaquin river systems of California. Therefore, it is possible to determine the synonymies of $H$. olidus and the members of the $H$. nipponensis species-group based on the geographical distributions of specimens reported in earlier works.

Taranetz (1935) described two subspecies of $H$. olidus: $H$. olidus drjagini and $H$. olidus bergi, both considered by McAllister (1963) to be invalid. In our examination of material borrowed from the Museum of Comparative Zoology, we found a lot of five specimens labeled $H$. olidus bergi (MCZ 34244). These specimens, collected in 1934 from a lake in the basin of the Tym River, Sakhalin, Russia (see Taranetz 1935), are most probably part of the type series of $H$. olidus bergi. The pneumatic duct of each of three examined specimens from this lot is connected posterior to the anteriormost tip of the gas bladder, a diagnostic character of $\mathrm{H}$. olidus. Close examination of these specimens revealed no significant differences in either meristic or morphological characters, thus eliminating any justification for recognizing $H$. olidus bergi.

\section{Hypomesus japonicus species-group}

Diagnosis. Nares with small narial septum; pneumatic duct extending from anteriormost tip of gas bladder; dorsal fin originating anterior to pelvic fin origin; pyloric caeca 6 (4-8), one pair elongate; mid lateral-line scales 65-68 (59-76); cephalic sensory pores small.

\section{Hypomesus japonicus (Brevoort, 1856) Japanese name: Chika}

(Fig. 4E)

Osmerus japonicus- Brevoort 1856: 278, pl. 10, fig. 2 (Hakodate, Japan; Osmerus olidus in text, Osmerus japonicus in figure.).

Osmerus oligodon- Kner 1865: 9, fig. 1.

Hypomesus pretiosus- Jordan and Evermann 1896: 231 (partim); Berg 1948: 477, fig. 
271 (Sovetskaya Harbor, Russia); Schmidt 1950: 34(partim); Lindberg and Legeza 1965: 97, figs 117, 118 (Maritime Territory, Russia).

Mesopus japonicus- Jordan and Snyder 1902: 589 (Kushiro, Hokkaido, and Aomori, Japan).

Spirinchus verencundus- Jordan and Metz 1913: 11, pl. 1, fig. 2 (Chinnampo, Korea). Hypomesus verencundus- Hubbs 1925: 51 (key); Lindberg and Legeza 1965: 100, fig. 119.

Hypomesus japonicus- Hubbs 1925: 51 (key)(partim); Hamada 1954: 260 (key); Okada 1959: 350, fig. 55; Hamada 1961: 13-39; Kljukanov 1970a: 415; Kljukanov 1970b: 1541 (key); Gritzenko and Churikov 1983: 553 (key).

Hypomesus pretiosus japonicus- McAllister 1963: 30, fig. 9 (type not specified; BC60-154: Shokotsu River, Hokkaido, Japan; NMC60-496: Mori, Japan Sea, Hokkaido, Japan; UMMZ145811: Avatcha Bay, Kamchatka, Russia); Masuda et al. 1984: 33, pl. 36H.

Material examined. ANSP 26378, 6 specimens, damaged, SL not recorded, Aomori, Japan, 1900. CAS 106774, 1 specimen, 144.4mm SL, Mutsu Bay, Aomori, Japan, 1900; CAS 123881, 1 specimen, 121.2mm SL, Chinnampo, S. P'yongan Province, Korea (paratype of Spirinchus verencundus); CAS 6796, 1 specimen, $146.7 \mathrm{~mm}$ SL, Kushiro, Hokkaido, Japan. UMMZ 145811, 1 specimen, $113.1 \mathrm{~mm}$ SL, Avatcha Bay, Kamchatka, 1930. UW 26938, 8 specimens, 127.3-151.6mm SL, Abashiri, Hokkaido, 24 November 1995; UW 27617, 10 specimens, 62.7-76.0mm SL, Lake Tohutsu, Hokkaido, Japan, 11 November 1994; UW 40201, 10 specimens, 124.7-137.0mm SL, Yuzhno-Kurilsk fishing pier, Kunashir Island, 1 September 1995; UW 40203, 10 specimens, 122.6-147.4mm SL, Yuzhno-Kurilsk fishing pier, Kunashir Island, 1 September 1995.

Diagnosis. Vomer large, with broad, bifurcated posterior process (Fig. 2E); periphery of glossohyal bone with row of conical teeth, a few similar teeth located more centrally (Fig. 3E); gill rakers $11(9-13)+23(23-26)=35(30-37)$; vertebrae $41(39-42)+22(20-23)=62(59-64)$; pyloric caeca $6(4-7)$; base of adipose fin less than $20 \%$ of HL; eye small, diameter 25 (19-31)\% of HL; adipose eyelid poorly developed; other characters as for $\mathrm{H}$. japonicus species-group.

Description. Dorsal fin rays 10 (9-11); anal fin rays 15 (14-19); pectoral fin rays 13 (10-16); pelvic fin rays 8 (8-9); mid lateral-line scales 65 (59-69); transverse scales 16 (13-19); dorsal fin originating dorsal to vertebra 28 (26-29); pelvic fin originating ventral to vertebra 29 (28-30); anus located ventral to vertebra 46 (43-49) (Table 2).

Head small, length 22 (20-26)\% of SL, depth 49 (44-54)\% of HL; snout length 30 (23-40)\% of HL, width 26 (18-42)\% of HL; gape of mouth $35(32-41) \%$ of HL; interorbital region slightly convex, wide and flat at top, dorsal margin of eye located below dorsal margin of head; interorbital width 27 (22-31)\% of HL; body depth at opercle 65 (55-74)\% of HL; snout to dorsal fin origin 49 (47-54)\% of SL; snout to pelvic fin origin 51 (48-54)\% of SL; snout to anus 75 (72-78)\% of SL; depth of caudal peduncle 30 (24-33)\% of HL. For additional proportional data, see Tables 3-5.

Color after preservation. Light beige or tan overall, darker dorsally. A silvery stripe running full length of body, increasing in width progressively toward tail.

Distribution. From Pacific coast of Japan north of Sendai, Miyagi Prefecture, to Peter the Great Bay, Russia (Fig. 6).

Life history. A spring spawning, marine coastal species. Spawning takes place on 
beaches. Most of the population spawn the first year and die, but significant numbers survive to spawn a second or third year and there are even records of individuals surviving to a fourth year (Yanagawa 1981).

Comments. Kljukanov (1970a, b) elevated all of the subspecies of McAllister (1963) to full species rank based on differences in osteological characters. Other than the shape of the vomer, which Kljukanov was first to describe, we found clear differences in vertebral counts. Differences between $H$. japonicus and $H$. pretiosus, with virtually no overlap, were found in the locations of the dorsal fin origin, pelvic fin origin, and anus with respect to vertebrae, and in the number of precaudal vertebrae (Table 2). Based on combinations of these characters, H. japonicus and $H$. pretiosus are here recognized as valid species.

The figure of $H$. oligodon published by Kner (1865) shows 68 mid lateral-line scales, thus placing $H$. oligodon in the $H$. japonicus species-group. Mid lateral-line scale counts for the other members of this group, H. japonicus and H. pretiosus, are 65 (50-69) and 68 (65-76), respectively. Although the count for $H$. oligodon is closer to that of $H$. pretiosus, $H$. oligodon is regarded as a synonym of $H$. japonicus based on geographic distribution: $H$. japonicus and the type material of $H$. oligodon are from the Western Pacific; $H$. pretiosus is confined to the Pacific coast of North America from California to Alaska.

Examination of the paratype of $H$. verencundus (CAS 123881), collected from Chinnampo, Korea, failed to reveal any significant difference from $H$. japonicus and thus it, too, is regarded as a junior synonym of the latter species.

\section{Hypomesus pretiosus (Girard, 1854) \\ English name: Surf Smelt}

(Fig. 4F)

Argentina pretiosa- Girard 1854: 155 (Presidio, California, USA).

Hypomesus pretiosus- Jordan and Evermann 1896: 525, pl. 86, fig. 230 (coasts of California and Oregon) (partim); Jordan and Evermann 1902: 231; Hubbs 1925: 51 (key); Schmidt 1950: 34(partim); Roedel 1953: 39, fig. 37; Wilimovsky 1954: 282; Kljukanov 1970a: 415; Kljukanov 1970b: 1540 (key); Gritzenko and Churikov 1983: 553 (key).

Hypomesus pretiosus pretiosus- McAllister 1963: 28, fig. 9 (type not designated; San Francisco Bay, California, to Prince William Sound, Alaska, USA); Hart 1973: 137 (key), 139 (figure).

Material examined. CU 35074, 1 specimen, 106.2mm SL, San Pablo Bay, Rodeo, California, 19 October 1956; CU 3948, 5 specimens, 94.5-103.2mm SL, Siuslaw River, Oregon, 8 December 1896; CU 56199, 2 specimens, 50.2-54.3mm SL, Eagle Cove, San Juan Islands, Washington, 25 June 1979. MCZ 6983, 1 specimen, 152.3mm SL, San Francisco, California, mid-1800s; MCZ 34867, 1 (of 2) specimens, $151.4 \mathrm{~mm} \mathrm{SL,} \mathrm{San}$ Francisco, California. UMMZ 60903, 10 specimens, 86.5-124.2mm SL, San Francisco Bay, 17 April 1923; UMMZ 182236, 3 specimens, 73.0-78.7mm SL, Little Port Walter, Baranof Island, Alaska, 27 June 1958; UMMZ 182242, 4 specimens, 72.5-76.2mm SL, Little Port Walter, Baranof Island, Alaska, 27 June 1958; UMMZ 182319, 1 specimen, 93.3mm SL, Sashin Creek, Baranof Island, Port Herbert, Alaska, 23 July 1958. UW 
6331, 10 specimens, 89.2-109.2mm SL, Useless Bay, Puget Sound, Washington, 16 July 1938; UW 8383, 10 specimens, 134.7-153.8mm SL, Purdy, Washington; UW 1171 , 3 specimens, $81.5-85.7 \mathrm{~mm}$ SL, False Bay, San Juan Islands, Washington, 13 July 1930; UW 15528, 6 specimens, 114.0-121.7mm SL, Yakutat Bay, Alaska, 5 July 1960.

Diagnosis. Vomer small, without posterior process (Fig. 2F); periphery of glossohyal bone with single row of blunt teeth, a few teeth located irregularly at center of distal region (Fig. 3F); gill rakers $11(9-13)+22(20-25)=33(30-36)$, vertebrae $44(41-45)+22(21-23)=66(64-67)$; pyloric caeca $6(4-8)$; base of adipose fin less than $20 \%$ of HL; eye small, diameter 23 (17-28)\% of HL; adipose eyelid well developed; other characters as for $H$. japonicus species-group.

Description. Dorsal fin rays 10 (9-11); anal fin rays 15 (12-17); pectoral fin rays 15 (13-16); pelvic fin rays 8 (8-9); mid lateral-line scales 68 (65-76); transverse scales 19 (15-25); dorsal fin originating dorsal to vertebra 31 (30-33); pelvic fin originating ventral to vertebra 33 (31-34); anus located ventral to vertebra 50 (48-51) (Table 2).

Head small, length 21 (19-24)\% of SL, depth 49 (42-67)\% of HL; snout length 29 $(21-41) \%$ of HL, width 23 (16-39)\% of HL; gape of mouth $36(32-44) \%$ of HL; interorbital region slightly elevated, flat at top, dorsal margin of eye located slightly below dorsal margin of head; interorbital width 26 (22-33)\% of HL; body depth at opercle 64 (54-76)\% of HL; snout to dorsal fin origin 51 (47-54)\% of SL; snout to pelvic fin origin 53 (49-58)\% of SL; snout to anus 76 (70-79)\% of SL; depth of caudal peduncle 31 (25-39)\% of HL. For additional proportional data, see Tables 3-5.

Color af ter preservation. Light beige to tan overall, darker dorsally. Single dark stripe running full length of body.

Distribution. Pacific coast of North America from Long Beach, California, to Prince William Sound, Alaska (Fig. 6).

Life history. Spawning takes place year round during high tide. Eggs are laid on beaches with heavy surf action or where drying of adhesive eggs laid and buried in the sand can be avoided. The main diet consists of zooplankton (Hart 1973).

Comments. See those for $H$. japonicus.

\section{Acknowledgments}

We thank the following individuals for providing loans of specimens: David Catania, Department of Ichthyology, California Academy of Sciences; Charles Dardia, Ichthyological Collection, Cornell University; Karsten Hartel, Museum of Comparative Zoology, Harvard University; Yoshihiro Matsumoto and Tooru Mukai, Akkeshi Marine Biological Station, Hokkaido University; Douglas Nelson, Division of Fishes, Museum of Zoology, University of Michigan; Takao Nemoto, Inland Fisheries Experimental Station, Ibaraki Prefecture; Mary Anne Rogers, Division of Fishes, Field Museum of Natural History; Scott Schaefer, Department of Ichthyology, Academy of Natural Sciences of Philadelphia; Gento Shinohara, National Science Museum, Tokyo; Brian Urbain, School of Fisheries, University of Washington; Yukio Yamazaki and Koki Ishikawa, Fisheries Experimental Station, Ibaraki Prefecture.

The work described here was accomplished while the senior author was in residence at the School of Fisheries, University of Washington, as a Visiting Scholar, made possible in part by a fellowship from the Overseas Researcher Program of the Ministry of Education, Science, Sports, and Culture of Japan. The research was 
supported in part by the Biological Sciences Directorate (Biotic Surveys and Inventories Program) and the International Programs Division of the United States National Science Foundation, grant numbers DEB-9400821 and DEB-9505031, Theodore W. Pietsch, principal investigator.

\section{References}

Andriyashev, A. P. 1954. Fishes of the Northerm Seas of the U.S.S.R. Keys to the fauna of the U.S.S.R. No. 53. Zoological Institute of the U.S.S.R. Academy of Sciences, MoscowLeningrad, $617 \mathrm{pp}$. [Translated from the Russian, Israel Program for Scientific Translations, Jerusalem, 1964.]

Berg, L. S. 1948. Freshwater Fishes of the U.S.S.R. and Adjacent Countries. Vol. 1. Guide to the fauna of U.S.S.R. No. 27. Academy of Sciences of the U.S.S.R., Zoological Institute, MoscowLeningrad, 504 pp. [Translated from the Russian, Israel Program for Scientific Publications, Jerusalem, 1962.]

Brevoort, J. C. 1856. Notes on some figures of Japanese fish. Pp. 253-256, PIs. III-XII, In: Narrative of Commodore M. C. Perry's Expedition to Japan.Vol. II. Washington, D.C., v $+414 \mathrm{pp}+\mathrm{xi} p$. XII Nat.Hist. pls. [with fac-simile of the original treaty with Japan, $14 \mathrm{pp}$. and 17 charts.]

Eschmeyer, W. N. 1990. Catalog of the Genera of Recent Fishes. California Academy of Sciences, San Francisco, v+697pp.

Evermann, B. W. and Goldsborough, E. L. 1907. The fishes of Alaska. Bulletin of the U.S. Bureau of Fisheries 26: 221-360.

Gilbert, C. H. and Burke, C. V. 1912. Fishes from Bering Sea and Kamchatka. Bulletin of the U.S. Bureau of Fisheries 30: 33-96.

Gill, T. 1862a. On the subfamily Argentininae. Proceedings of the Academy of Natural Sciences of Philadelphia 14(1-2): 14-15.

Gill, T. 1862b. Notes on some genera of fishes of western North America. Proceedings of the Academy of Natural Sciences of Philadelphia 14(7-9): 329-332.

Girard, C. 1854. Observations upon a collection of fishes made on the Pacific coast of the United States, by Lieut. W. P. Trowbridge, U.S.A., for the museum of the Smithsonian Institution. Proceedings of the Academy of Natural Sciences of Philadelphia 7(4): 142-156.

Gritzenko, O. F. and Churikov, A. A. 1983. Taxonomy of smelts of the genus Hypomesus (Salmoniformes, Osmeridae) on the Asian coast of the Pacific Ocean. Zoologicheskiy Zhurnal 62 (4): 553-563. [In Russian with English abstract.]

Hamada, K. 1954. Revision of Hypomesus olidus (PALLAS) and Hypomesus japonicus (BREVOORT) of Hokkaido, Japan. Bulletin of the Faculty of Fisheries, Hokkaido University 4 (4): 256-267.

Hamada, K. 1957. A new osmerid fish, Hypomesus sakhalinus new species, obtained from Lake Taraika, Sakhalin. Japanese Journal of Ichthyology 5 (3/6): 136-142.

Hamada, K. 1961. Taxonomic and ecological studies of the genus Hypomesus of Japan. Memoirs of the Faculty of Fisheries, Hokkaido University 9 (1): 1-56.

Hart, J. L. 1973. Pacific Fishes of Canada. Fisheries Research Board of Canada, Ottawa, Bulletin 180 , ix +740 pp.

Hubbs, C. L. 1925. A revision of the osmerid fishes of the north Pacific. Proceedings of the Biological Society of Washington 38: 49-56.

ICZN. 1985. International Code of Zoological Nomenclature. Third edition. University of California Press, Berkeley and Los Angeles, $\mathrm{xx}+338 \mathrm{pp}$. 
Jordan, D. S. 1919. The Genera of Fishes. Part III. From Guenther to Gill, 1859-1880, Twenty-Two Years, With the Accepted Type of Each. A Contribution to the Stability of Scientific Nomenclature. Stanford University, Stanford, California, No. 39, 285-410

Jordan, D. S. and Evermann, B. W. 1896. The fishes of North and Middle America, a descriptive catalogue of the species of fish-like vertebrates found in the waters of North America, north of the isthmus of Panama. Bulletin of the U.S. National Museum 47 (1). Lx 954 pp.

Jordan, D. S. and Evermann, B. W. 1902. American Food and Game Fishes. A Popular Account of All the Species Found in America North of the Equator, With Keys for Ready Identification, Life Histories and Methods for Capture. Dover Publications, Inc., New York, USA, xiix +574pp.

Jordan, D. S. and Metz, C. W. 1913. A catalogue of the fishes known from the waters of Korea. Memoirs of the Carnegie Museum 6(1): 1-65.

Jordan, D. S. and Snyder, J. O. 1902. A review of the salmonid fishes of Japan. Proceedings of the U.S. National Museum 29 (1265): 567-593.

Katayama, S. Hishida, M., and Okata, A. 1996. Morphometric and reproductive characteristics of the pond smelt population in Lake Ogawara. Tohoku Journal of Agricultural Research 46 (3-4): 125-140.

Katayama, S. and Kawasaki, T. 1994. Age determination of pond smelt using otolith phase. Tohoku Journal of Agricultural Rescarch 44 (1-4): 91-106.

Katayama, S. and Okata, A. 1995. Pond Smelt spawning in the inflowing river into Lake Ogawara. Tohoku Journal of Agricultural Research 45 (3): 87-102.

Kljukanov, V. A. 1970a. Classification of smelts (Osmeridae) with respect to peculiarities of skeleton structure in the genus Thaleichthys. Zoologicheskiy Zhurnal 49: 399-417.

Kljukanov, V. A. 1970b. Morphological basis of the classification of smelts of the genus Hypomesus. Zoologicheskiy Zhurnal 49: 1534-1542.

Kner, R. 1865. Fische aus dem naturhistorischen Museum der Herren J. C. Godeffroy and Sohn in Hamburg. Denkschriften der Akademie der Wissenschaften, Wien 24: 1-12.

Lindberg, G. U. and Legeza, M. I. 1965. Fishes of the Sea of Japan and the Adjacent Areas of the Sea of Okhotsk and the Yellow Sea. Part 2. Teleostomi XII. Acipenseriformes-XXVIII. Polynemiformes. Keys to the fauna of the U.S.S.R. No. 84. Academy of Sciences of the U.S.S.R., Zoological Institute, Moscow-Leningrad, v+498pp. [Translated from the Russian, Israel Program for Scientific Translations, Jerusalem, 1969.]

Masuda, H., Amaoka, K., Araga, C., Uyeno, T., and Yoshino, T. (Eds.). 1984. The Fishes of the Japanese Archipelago. Tokai University Press, Tokyo, xxii +437pp. pls. 1-370.

McAllister, D. E. 1963. Revision of the smelt family, Osmeridae. National Museum of Canada Bulletin No. 191, Biological Series No. 71, iv +53pp.

Moyle, P. B. and Herbold, B. 1992. Life history and status of delta smelt in the Sacramento-San Joaquin estuary, California. Transactions of the American Fisheries Society 121:67-77.

Okada, Y. 1959. Studies on the Freshwater Fishes of Japan. Prefectural University of Mie, Tsu, Japan, 860pp.

Pallas, P. S. 1814. Zoographia Rosso-Asiatica, sistens omnium animalium in extenso Imperio Rossico et adjacentibus maribus observatorum recensionem, domicilia, mores et descriptiones, anatomen atque icones plurimorum. In Officina Caes. Academie Scientiarum Impress, St. Petersburg, Vol. 3: vii +428pp.+index (1-CXXV)

Potthoff, T. 1984. Clearing and staining techniques. Pp. 35-37, In: Moser, H. G., Richards, W. J., Cohen, D. M., Fahay, M. P., Kendall, A. W., Jr., and Richardson, S. L. (Eds.) Ontogeny and Systematics of Fishes. American Society of Ichthyologists and Herpetologists Special Publication No. 1, ix +760pp.

Roedel, P. M. 1953. Common ocean fishes of the California coast. California Department of Fish 
and Game, Fish Bulletin 91. 184pp.

Saruwatari, T. López, J. A., and Pietsch, T. W. 1996. A revision of the osmerid genus Hypomesus, with the description of a new species from the Kuril Islands. p. 273, In: Program and abstracts. American Society of Ichthyologists and Herpetologists, 76th Annual Meeting, June 13-19, 1996. [Abstract only.]

Saruwatari, T. and Kaneko, A. 1996. Larval fish clamp: a tool for observing larval fishes. Copeia 1996(1):221-223.

Saruwatari, T., and Okiyama, M. 1992. Life history of shirauo, Salangichthys microdon, Salangidac, in a brackish lake, Lake Hinuma, Japan. Nippon Suisan Gakkaishi 58 (2): 235-248.

Sato, R. 1952. Biological observation on the pond smelt, Hypomesus olidus (Pallas), in Lake Kogawara, Aomori Prefecture, Japan. II. Early life history of the fish. Tohoku Journal of Agricultural Research 3 (1): 175-184.

Sato, R. 1953. Biological observation on the pond smelt, Hypomesus olidus (Pallas), in Lake Kogawara, Aomori Prefecture, Japan. III. Annual cycle of ecological elements in relation to production of food organisms of the fish. Tohoku Journal of Agricultural Research 4 (1): $55-74$.

Schmidt, P. Y. 1950. Fishes of the Sea of Okhotsk. Academy of Sciences of the U.S.S.R., Transactions of the Pacific Committee, Vol. 6, xiv +392pp. [Translated from the Russian, Isracl Program for Scientific Translations, Jerusalem, 1965.]

Taranetz, A. 1935. On some fishes from Sakhalin. Bulletin of the Far Eastern Branch of the Academy of Sciences of the U.S.S.R. 15: 85-88. [In Russian, with English summary.]

Turner, L. M. 1886. Part IV. Fishes. Pp. 87-113, In: Contributions to the Natural History of Alaska. Results of Investigations Made Chiefly in the Yukon District and the Aleutian Islands; Conducted Under the Auspices of the Signal Service, United States Army, Extending from May, 1874, to August, 1881. Government Printing Office, Washington, D.C., 266pp.

Wales, J. H. 1962. Introduction of the pond smelt from Japan into California. California Fish and Game 48: 141-142.

Wilimovsky, N. J. 1954. List of the fishes of Alaska. Stanford Ichthyological Bulletin 4 (5): 279-294.

Yanagawa, H. 1981. Studies on the local form and dispersal of the Chika, Hypomesus pretiosus japonicus (Brevoort) in Japan. Memoirs of the Faculty of Fisheries, Hokkaido University 27(1/2): 1-78. 